\title{
Culture, Cognition and Language in the Constitution of Reading and Writing Practices in an Adult Literacy Classroom
}

\author{
Cultura, Cognição e Linguagem na Constituição de Práticas de Leitura \\ e Escrita de Adultos em Processo de Alfabetização
}

\author{
Maria de Fátima Cardoso Gomes *, Maria da Conceição Ferreira Reis Fonseca, \\ Maira Tomayno de Melo Dias \& Patricia Guimarães Vargas \\ Universidade Federal de Minas Gerais, Belo Horizonte, Brasil
}

\begin{abstract}
In this article we analyze a discursive interaction between a researcher and an Youth and Adult Education student intending to show the meanings and uses of reading and writing taken by him. We take as our basis for discussion the theoretical-methodological contributions from Historical-Cultural Psychology and Paulo Freire's theories, which are combined with Bakhtin's concept of dialogue. This procedure allowed us, on one hand, getting into the other's perspective and, on the other hand, to make relations between cognition, language and culture to understand the adult students' metacognitive strategies, in the appropriation process of literacy practices of school culture. Thus, we could discuss the intimate relationship between doing and knowing and the importance of school in the transition from concrete thinking to the abstract thinking and vice-versa.

Keywords: Adult Education; Reading and Writing; Language; Culture; Cognition.

Resumo

Neste artigo analisamos uma interação discursiva entre uma pesquisadora e um estudante da Educação de Jovens e Adultos objetivando mostrar sentidos e usos da leitura e da escrita por ele mobilizados. Tomamos como base para nossa discussão os aportes teórico-metodológicos da Psicologia Histórico-Cultural e das teorizações de Paulo Freire, que conjugamos com a concepção de diálogo de Bakhtin. Tal procedimento nos possibilitou, por um lado, entrar na perspectiva do outro, e por outro, fazer relações entre cognição, linguagem e cultura para compreendermos as estratégias metacognitivas de alunos da EJA ao se apropriarem da cultura escolar. Pudemos também evidenciar a íntima relação entre fazer e saber e a importância da escola na transição do pensamento concreto para o abstrato e vice-versa.

Palavras-chave: Educação de Jovens e Adultos; Leitura e Escrita; Linguagem; Cultura; Cognição.
\end{abstract}

The analysis presented in this text was produced from a survey in which, concerned with the issue of educational exclusion of many Brazilian citizens, whether children or adults, we seek, among other objectives, to understand some of the meanings and senses (Vygotsky, 1934/1993) of reading and writing, which were constructed by students of the school Adults Education (AE) in the interface between school learning and the use they make of reading and writing in their everyday lives.

In this analysis, we take from Vygotsky (1989, 1934/ 1993) the hypothesis that the intersubjective learning of reading and writing is reworked internally by the student and the product of this internalization is qualitatively

* Address: Universidade Federal de Minas Gerais, Faculdade de Educação, Centro de Alfabetização, Leitura e Escrita, Laboratório de Psicologia e Educação Helena Antipoff, Campus Pampulha, Av. Antônio Carlos, 6627, Belo Horizonte, MG, Brazil, CEP 31270-901. E-mail: mafacg@gmail.com different from that produced on the interpersonal level. However, for awareness of this internal reworking, it is necessary to establish dialogue in the classroom, allowing students to speak about their own learning processes, so that, assuming a metacognitive approach, they can become aware of what and how they learned and, thus, evidence for themselves and for others the meanings they have built by the acts of reading and writing, inside and outside of school.

The perspective from which we approach metacognition is similar to that assumed by Fonseca (2001), in giving prominence to the rhetorical and argumentative base of the metacognitive processes. As in that study, we return to the understanding that oriented the collected works of Middleton and Edwards (1990a), moving us closer to reflection on the plausibility of a dialogical basis of human thought (Vygotsky, 1989, 1934/1993; Wertsch, 1988), when considering metacognition as "the development of a culturally shared discourse that serves to make statements about mental processes, to argue, justify 
and make the others realize what we want to know" (Middleton \& Edwards, 1990b, p. 45), "and that which we confess we do not know" (Fonseca, 2001, p. 349).

Hence, we take Bakhtin's conception of dialogue (1992), which we combine with Freire's (1970/2005), to give support to our exercise in understanding another's perspective, and our willingness to know their thoughts, intentions and feelings about learning through reading and writing. Thus, we work with the concepts of meaning (social) and sense (personal) developed by Vygotsky (1934/1979), based on studies by Paulhan, the author with whom he converses in the text Thought and Language, by assuming that:

the meaning of a word is the sum of all the psychological events that the word awakens in our consciousness. It is a complex, fluid, dynamic which has several zones of unequal stability. The meaning is no more than one of the zones of sense, which is the most stable and accurate. A word derives its meaning from the context in which it arises; when the context changes, the meaning changes as well. The meaning remains stable through all changes of sense (p. 191).

To capture the relationship between culture, cognition and language and the meanings produced by adult students in literacy process, we adopt ethnography as a methodology, developing a survey, with a longitudinal character, in that we accompany an Education of Youth and Adults class, from the initial enrollment and during three years. Of the empirical material produced in this study, we have selected a discursive interaction between a researcher and an adult student, Mr. Sebastião (the use of the student's real name, and that of the others, was permitted by the students), whose analysis, based on theoretical and methodological principles of Interactional Ethnography, the theories of Paulo Freire and the Historical-Cultural Psychology, is what we intend to present this article.

\section{Theoretical and Methodological Assumptions}

The methodology used in this research that afforded us the production of the material analyzed here is based on Interactional Ethnography (Santa Barbara Classroom Discourse Group, 1992). We seek to develop an investigative logic based on the understanding of classroom dynamics as a socially constructed practice by members of a group. From this point of view, we understand that the participants (teachers and students) will set the standards for action and use of language, that is, they will produce the classroom culture, which is taken as a reference for engaging in activities that the classes will develop. In agreement with Collins and Green (1992), and Green and Harker (1982), we consider that the classroom functions as a culture, whose members reconstruct ways to interact with one another and with the objects in the cultural practices in which they participate. These forms of interaction among group members, in turn, lead not only to the establishment of particular forms of doing and knowing, but also to the construction of common knowledge and framework that guide the interpretation and participation in the group.

From this perspective, according to Green and Wallat (1981) and Gumperz (1986), the class is constituted through instructional conversations that are part of the life of the classroom. In order to understand the meanings that Mr. Sebastião has built about reading and writing, we utilize a microgenetic analysis to contemplate an event that the student protagonizes and the social processes that engender such an event. Góes (2000) clarifies that such an analysis is considered as micro "to be oriented towards the minutiae indexed - resulting in the necessity of excerpts of a period that tends to be restricted" (p. 15). It is, however, from the "genetic [analysis] in the sense of being historical, by focusing on the movement during processes and conditions relating past and present, trying to explore what, at present, is pregnant with future projection” (Góes, 2000, p. 15). The analysis we undertake is therefore sociogenetic "in seeking to relate the singular events with other cultural plans, social practices, circular discourse, and institutional spheres” (Góes, 2000, p. 15).

This is, principally, to construct, obtain, and ascribe meaning to what is learned through use and functions of written language that are relevant and meaningful to learners. For Vygotsky, writing is a symbolic activity, like other symbolic activities (gesturing, drawing, games, etc.), involving the representation of one thing for another, the use of auxiliary signals to represent meaning (Fontana \& Cruz, 1997). So, what it means to learn to read and write, in the context of the classroom, can only be examined if they are considered discursive interactions, the actions of participants and their social and singular stories (Castanheira, 2004; Gomes, Dias, \& Silva, 2008; Gomes \& Mortimer, 2008). This implies teaching/learning the written language and not just writing letters, as stated by Vygotsky (1934/1993). It spotlights the need for social interaction between students and teachers and among students themselves, in order for them to construct the activity, the use, the practice, and the knowing how to read and to write as discursive processes (Smolka, 1999).

Therefore, assuming this conception of learning to read and write and the logic that we set forth to give to our research, the understanding of the relationship between culture and cognition, already widely studied by many scholars like Bruner (1990/1997, 1996/2001), Cole (2006), Cole and Scribner (1974), Oliveira (2009), Oliveira and Oliveira (1999), demands, from our point of view, the establishment of a link between such relationships and a theoretical perspective of the speech and language. This is because we consider language as a labor (Orlandi, 1987), a sociocultural practice of a group, its activities, and its social environment. It is therefore more than the writing of speech and the reading of transcribed data: it involves a particular perspective of discourse and social action of a particular group (Gee \& Green, 1998). 
Spradley (1980) affirms that it is through discourse analysis that we can identify what the actors of a social group produce as cultural models, understanding, as cultural models, the way of life, the way of being, experiencing the world of the participants. Thus, the study of cultural models is done through the ethnographic perspective, guided by the analysis of discourse that, in the words of Fairclough:

is not simply an analysis of the form as opposed to the analysis of the content or meaning . . . it is a dynamic and dialectical intertextual analysis such as that conceived by Bakhtin (1992), and may mediate the connection between language and social context. (1993, p. 184).

In this study we articulate, therefore, the ethnographic approach to discourse analysis and the historical-cultural theory of Vygotsky (1934/1993), considering that the subject is social and that, through social interactions, is also constructed as a singular subject. The uniqueness or particularity is, therefore, constructed socially and by the mediation of language, culture, and others. Thus, as we place one of the research subjects (Mr. Sebastião) in the center of the analysis, we recognize that his individual construction of written language was forged in the social interactions of the classroom, that is, through the mediation of the teacher and his peers, which was provided by daily contact over two years and which constituted - and also derived - the constructions that Mr. Sebastião made of non-educational opportunities in which he deals with written records. From this perspective, cognition itself is revealed as a social process, mediated by others and by language. The cognitive activity is taken as intersubjective and discursive (Fontana, 1996). Thus, internalization of everyday and educational concepts by the adults move from the interpersonal level to the intrapersonal level, the latter, according to Vygotsky (1934/1993), being an internal redesign of the interpersonal process. Thus, the word is the mediator of this internalization process of concepts. In the historical-cultural perspective, the concepts "are not analyzed as intrinsic categories of the mind, nor as a reflection of individual experience, but as historical products and significant mental activity mobilized in the service of communication, knowledge and problemsolving” (Fontana, 1996, p. 13).

In the reflection we propose herein, we will focus on the tension between the concepts of reading and writing forged in the daily of life a roofer and that (those) propagated by the school. In this investigative exercise, we will take ownership of the discussion developed by Vygotsky (1989) on the relationship between everyday concepts and scientific concepts, to examine the clash between the concepts of reading and writing that $\mathrm{Mr}$. Sebastião brings to the dialogue with the researcher and the educational concepts that circulate in the classroom. We will consider both those concepts emphasized by the pedagogical actions of the teacher (based on decoding), and those who support the research then in progress (who consider awareness of the uses and functions of writing to be critical for literacy). Thus, we work with the idea that concepts are tools for the decontextualization of the immediate reality, of change from a situational mode to an abstract mode of thinking, as well as enabling the development of metacognitive processes that promote a new departure from the world of experience (Oliveira, 1999).

And, once again, in agreement with Vygotsky, we assume that the development of concepts involves linguistic, cognitive, affective, and sociocultural identity aspects, implying, therefore, the consideration of relationships between the concepts built into the educational environment (which in this analysis assume of role that Vygotsky attributes to the scientific concept), and the concepts built in other areas of social life (that herein behave like what he calls everyday concepts), as constituting the process of concept development. For Vygotsky (1934/1993), the strength of everyday concepts is the weakness of scientific/educational concepts and vice versa. The everyday concepts are embedded in the personal experience of the subjects, and the scientific concepts are presented by the teachers and do not enter in everyday life, yet they require the concept of everyday experiences and of the experiences to develop. Learners, in order to assimilate the scientific concepts, remake and interpret them in their own way.

In the episode analyzed herein, Mr. Sebastião, prompted by the researcher's question on learning of reading and writing in the first two years at the school, displays of his private record of a quantity of pieces of wood and measurements of the pieces necessary for the construction of a hypothetical roof. It is this attitude that instills the dialectical relationship in which educational concepts and daily life meet. The scientific/school conception of reading and writing is questioned by the everyday uses of reading and writing for Mr. Sebastião. On the other hand, it is this educational conveyed by the researcher's question that allows the development of conceptions of reading and writing in everyday life of the subjects with little schooling, bringing them to the "systematization, consciousness and the deliberate use" (Fontana, 1996, p. 22) of the acts of reading and writing. In this movement lies the possibilities of cultural and mental development of adult education learners and educators at $\mathrm{AE}$, in a process of appropriation of reading and writing, as "the reflexive consciousness of the culture, the critical reconstruction of the human world, the opening of new pathways, the historical project of a common world, [and] the courage to say his word" (Freire, 1970/2005, p. 21).

\section{Analysis Procedures For Empirical Material}

The methodological procedures that we used throughout the research included: participant observation in the classroom and field notes, while we made video recordings of the classes; individual and collective interviews 
with the teacher and students; and the collection of artifacts produced by students and teacher.

From these procedures, we produced the empirical material, which was transcribed, initially in the Event Map form, with the objective of discerning how time was used, by whom, for what purpose, when, where, under what conditions, with what results, and in what manner group members signaled a change in classroom activities (Castanheira, 2004). For detailed analysis and discursive research material, we used transcription of the Discursive Sequence in Message Units (Green \& Wallat, 1981) that represent the smallest unit coded in the message system generated by social interactions. The message unit is the smallest unit of conversational meaning produced by speakers. Each message unit is defined in terms of its origin and form, its purpose and comprehension level and the links between them. The boundary of a message unit is linguistically marked by cues of contextualization. According to Gumperz (1986), these clues may be: verbal (intonation, pauses, and cuts of speech), nonverbal (gestures, facial expressions, miming), and co-verbal (prosodic), which can define a message or an event that want to analyze.

The discursive interactions we focus on in this article took place in the class on November 13, 2007, and integrate the first event that we identify which puts the class under analysis: an interview with the students (activity coordinated by the researchers). After the interview, three other events were identified: word dictation; syllabic separation, and individual writing of phrases using dictated words (activities coordinated by the teacher).

The event Interview with students was our choice to support this reflection on the meanings that students construct for learning to read and write, because the interlocutive game that it established helps us to better understand the links between culture, cognition and language. This interview lasted for $01 \mathrm{~h}: 00 \mathrm{~m}: 58 \mathrm{~s}$, and the transcript of discursive sequences totaled 3649 lines. However, we will examine in this article, the interactions presented between the lines 1833 and 1889, when dialogue takes place between the researcher and Mr. Sebastião.

This student was very active in class, interested in learning to read and write because he wanted a driver's license. He had not attended school as a child or adolescent, nor participated in any other AE initiative. When the episode analyzed herein occurred, he had attended this school for two years. He was 45 years old, married, with one son. He came from the Minas Gerais countryside, where he worked in a farm. In the state capital city of Belo Horizonte, he practiced the trade of roofing, which provided him with the learning that led him to build concepts, woven in the experiences of designing and assembling the roof timbers. Such concepts involve notions of length and area, measurement and estimative, angle and symmetry, strength and balance, and have developed in the practical and personal experience in roof construction, but also by social transmission, through the mediation of language, learning with guidance or reported experience of teachers or fellow craftsmen.

The researcher's conversation with the students, which took place prior to the interactions examined herein, was based on three central questions: "How did you learn to read and write here in school? What reading and writing activities facilitated learning for you? What do you read and write outside of school?" Questions that have become urgent by the end of the second year of research, because we wanted to know how each of them learned to read and write, and what this learning meant to them, in addition to the evidence of appropriation on the intersubjective plane, with which our empirical data was filled.

Many students expressed themselves during the interview, revealing the relationships that were built between their schooling and working worlds. When we thought that the interview had ended, a new round of conversation began, opened by Mr. Sebastião, who asks the researcher for permission to show her a record that he used to make in his work environment and would like her to read. The conversation that takes place between the researcher, the first author of this text, and Mr. Sebastião is what we analyze here, and that discursive interaction was chosen to lead this discussion because it exposes the relevant points we set out to analyze. Relevant points or Rich Points is a concept coined by Agar (2002) in order to cover facts that become visible where there is differentiation in frame of reference. Relevant points in ethnography, then, are those in which the differences of understanding, action, interpretation and participation become marked. At these points, the practices and cultural sources that members outline becomes visible in their efforts to maintain the participation as members of a classroom group (Green, Dixon, \& Zaharlic, 2001).

\section{"You See the Kind of Mind Of the People!"}

In the title of this subsection, which reproduces a statement delivered by Mr. Sebastião, reveals the core discussion of this article. He shows the researcher a record that he has made in the class: " 5 X P X 146 7", to answer the question "What do you read and write outside of school?” Adopting a discursive strategy different from that of his colleagues, he uses one of his own writings to illustrate his response.

In this way, in the discursive sequences in the table below, we see the sense of Mr. Sebastião's record constitutes, not in the record itself, but in the space of interaction between the student and researcher, reiterating what Orlandi affirms (1987): "the meaning of the text is not in any of the interlocutors, specifically; it is in the discursive space between the interlocutors" (p. 184). 
Gomes, M. F. C., Fonseca, M. C. F. R., Dias, M. T. M. \& Vargas, P. G. (2011). Culture, Cognition and Language in the Constitution of Reading and Writing Practices in an Adult Literacy Classroom.

Table 1

It starts a Dialogue between Student and Researcher

\begin{tabular}{|c|c|c|c|}
\hline Lines & Mr. Sebastião & Researcher & Contextualization \\
\hline 1833 & Look there teacher & & He gives a paper to the \\
\hline 1834 & Excuse me & & researcher where is written: \\
\hline 1835 & Do you understand this? & & $5 \times P X 1467$ \\
\hline 1836 & Take a look to check if you can & & \\
\hline 1837 & Read it for me & & The researcher tries \\
\hline 1838 & & Five times $\mathrm{P}$ & to decode the text written \\
\hline 1839 & & $P$ and 6 & by Mr. Sebastião - she reads \\
\hline 1840 & & $\mathrm{P}$ and 7 & numbers and letters separately. \\
\hline 1841 & You see & & \\
\hline 1842 & The kind of mind of the people & & \\
\hline 1843 & & What is it & \\
\hline 1844 & Sometimes I'm going to make a roof & & Mr. Sebastião decodes to the \\
\hline 1845 & Of a hundred meters & & researcher what he wrote - at \\
\hline 1846 & Of two hundred meters & & this point everybody \\
\hline 1847 & I write down it here by myself & & acknowledges the content of \\
\hline 1848 & I get there and I say & & the written text and the \\
\hline 1849 & I want five pieces & & meaning it has for the student. \\
\hline 1850 & Do you see the letter Pê & & \\
\hline 1851 & Fourteen by six & & \\
\hline 1852 & Of seven meters & & \\
\hline
\end{tabular}

Indeed, in the discursive sequences in this table, researcher and student share words and numbers that, supposedly, mean the same thing for both. However, the functions of letters and numbers in mental activity of each seem to be very different. Such activity is marked by the cultural practices of the subjects, forged in the workplace, in educational trajectories and other instances of social life.

What happens, at the beginning of these interactions, exposes the researcher's total lack of knowledge regarding the content and form of the student's text, which he, in turn, anticipates as the researcher's inability, challenging her proficiency as a reader ("Take a look to check if you can/read it for me"). Mr. Sebastião bet on the limitations that would be brought to the researcher by her not knowing about roof construction and not making an immediate connection with the record under the scope of this construction. In this context of dialogue, on one hand, the researcher uses knowledge of letters and numbers just as a beginning student of reading and writing would, who knows the letters and numbers but doesn't produce the expected meanings from them. On the other hand, it reveals the student's reflective movement in establishing discursive positions and constituting literacy practices, to bring the discussion on this record, to position themselves in relation to the uses of what they learned in school about reading and writing - thematic of the proposed interview by the researchers. In a way, the pragmatic function that the work experience confers on the written entry questions the educational view with which we conceive the form and intentions of writing:

1844 - Sometimes I'm going to make a roof / 1845 of a hundred meters / 1846 - of two hundred meters/ 1847 - I write down it here by myself / 1848 - I get there and I say / 1849 - I want five pieces / 1850 - Do you see the letter P / 1851 - Fourteen by six / 1852 By seven meters.

In these interactions, the student takes ownership of a text/annotation of the measurements of the wood pieces he'll need to make a roof ("I write down it here, by myself"). Making use of writing ("if I haven't write it down I was in trouble"), he reveals the inherent capacity of humans to make use of mediatory tools and signs to resolve a problem of everyday life (Vygotsky, 1934/1993). The record here does not have a communication function with another that reads it, but is a support for the memory of someone who writes it, to later retrieve information that will be communicated orally ("I get there andI say"), to someone who will make another record ("write down to me/like that like that") with another function: to make a budget.

If, in that format, Mr. Sebastião can make record for himself, to establish themes, within the school, the nature and form of the notation that he produce, he knows he will have to explain the significance of what he wrote. When available, therefore, to present and discuss this 
record, the student accepts the challenge of the researcher to reflect on the uses that he makes of reading and writing, and thus assumes a metacognitive approach.

The record and the opportunity that it tends to produce it mobilize different concepts related to roofing, such as: measurements of length and area, measurement units, angle, shape, relocating the material objects and produce including the possibility of creating a hypothetical situation ("sometimes I'm going to make a roof'), and generalizing ("of a hundred meters/of two hundred meters"). This shift allows the mediation of writing and speaking and assigning meaning to a record in negotiating with the functions of reading and writing that circulate inside and outside of school.

Still, Mr. Sebastião does not transcribe a text; he produces it, defining quantity of wood pieces that the roof demands. It seems that the five pieces to which he refers would be the beams - the wood pieces that support the roof - and that the "fourteen by six" which define its thickness are not established by calculation, but through knowledge of the list of cut pieces of wood on the market and the ones that are suitable will be used as beams. Though, based on that record, which is based on the example proposed by the roofer and in the discourse produced by the student, we could produce another text: 5 pieces of $14 \mathrm{~cm}$ by $6 \mathrm{~cm}$, of 7 meters. This record would still be insufficient to be understood by a reader who is outside of the situation in which discourse is produced, though he explicits, in the writing, the number of parts and their measurements: one cannot know through it, what these pieces are, the purpose of them, who needs them, how to get them, nor who is the speaker of the words. Only when Mr. Sebastião said "sometimes I'm going to make a roof" (line 1844) is it revealed to the researcher that his note refers to the construction material of roof and that he relies on the prior knowledge of his speaking partner that they are the required wood pieces for such a construction.

In the sequence, Mr. Sebastião takes care to establish parameters for the dimensions of the roof ("of $a$ hundred meters"; "of two hundred meters", lines 1845 and 1846), justifying the amount, thickness and length of the pieces. This shows the exercise to consistency checking between the textual content and production situation of the text.

From that point forward, we have discursive content that allows us to think about rewriting the entry made by Mr. Sebastião, moving towards the construction of a written text, with a beginning, middle and end, with cohesion and coherence, especially when he continues his speech: "I want five pieces/do you see the letter P/ fourteen by six / by seven meters" (lines 1849 to 1852).

It is interesting to note, based on these interactions, the constitutive role of culture producing shared symbolic systems, ways of living and working together, shared modes of discourse for negotiating differences of meaning and interpretation (Bruner, 1990/1997). Negotiations and sharing that, at school, can lead students to break free "from the immediate perceptual context, through the process of abstraction and generalization made possible by language" (Oliveira, 1999, p. 55). And, thus, allowing for the mediation of speech and writing, they communicate and reflect on their actions and thoughts, reformulating them. Every word (spoken or written) carries a generalization, is an act of verbal thought (Vygotsky, 1934/1993), is meaning produced by the praxis, whose discursivity flows from the storicity transforms the world, producing the kind of mind of the people, producing the kind of people, of sociocultural subjects that we are.

This dynamic movement of sociocultural constitution of subjects, in and through language, requires us to make connections between cognition, language and culture to better understand the metacognitive strategies of the $\mathrm{AE}$ students, in the process of appropriation of literacy practices of the educational culture. These strategies can hardly happen without school intervention (Oliveira, 1999). In the continuity of the explanation that Mr. Sebastião provides the researcher, with respect to the production situation of that entry, he continues his metacognitive exercise.

Mr. Sebastião said that if he haven't write it down, he was in trouble (line 1868) revealing to recognize, in writing, a support for memory and the organization of his acts and thoughts. Thinking thusly, he produces meanings for what he wrote. Through the mediation of writing, he anticipates and systemizes the demands (of wood), for himself. Through the mediation of speech, makes the necessary lumber purchases, but doesn't show the saleswoman his notes. Mr. Sebastião legitimizes the seller's writing, now in the context of budget production, elaborated from the demand he has presented.

To the saleswoman it is, however, only the transcription to a text written in the computer, of the text produced orally by Mr. Sebastião: "I go to the shop and see the lady/ I just tell to her, write down to me”. The rework that she lends to Mr. Sebastião's request does not include the calculation of how much wood will be needed to build the roof - definition of the scope of the roofer (the attributes of a roofer include building the wood frame of the roof, laying the tiles and sealcoating). The student roofer displays his expertise, which is not grounded in a conceptual approach of building roofs, but an elaboration based on the experience of many roofs built or constructions that were described by his teachers (master of roofers) and by colleagues (in this craft). That's what enables him to make roofs "the way it goes, round, square, any way". The appropriation of these work practices takes us to the work of Scribner and Cole (1981) and the observation of Bruner (1996/2001) that 
Gomes, M. F. C., Fonseca, M. C. F. R., Dias, M. T. M. \& Vargas, P. G. (2011). Culture, Cognition and Language in the Constitution of Reading and Writing Practices in an Adult Literacy Classroom.

Table 2

It Continues the Dialogue between the Student and Researcher

\begin{tabular}{llll}
\hline Lines & Mr. Sebastião & Researcher & Contextualization \\
\hline 1868 & If I haven't written it down I was in trouble & I see & $\begin{array}{c}\text { The conversation continues } \\
\text { in the lines 1853 a 1867. }\end{array}$ \\
1869 & & & \\
1870 & Ready & & \\
1872 & I go to the shop and see the lady & & \\
1873 & I just tell her & & \\
1874 & Write down to me & & \\
1875 & Like that, like that & & \\
1876 & And then my estimate gets ready & & \\
1877 & Then I make my roof & & \\
1878 & The way I can & That's cool! \\
1879 & Round & & \\
1880 & Square & & \\
1881 & Any way & \\
1882 & ((inaudible)) & \\
1883 & And the guy who & \\
1884 & Works with me & \\
1885 & ((inaudible)) & \\
1886 & How do you do this & \\
1887 & I said & & \\
1888 & In my head & & \\
1889 & in the head & & \\
\hline
\end{tabular}

"the mind is an extension of the hands and tools" and that "culture provides a rebus (in the classical sense) for cognitive activity” (p. 145). In the case of Mr. Sebastião, it was in the sharing of knowledge and practices, including practices of writing, that the roofer's identity and cognitive activity are constituted in and through language. And now, through the mediation of the school, this identity could be presented and reflected, both by Mr. Sebastião, and by the researcher and the dialogue participants in that classroom, producing shared meanings for what he does, what he writes, and what he doesn't read in the daily life of a roofer.

Mr. Sebastião said that he does all the calculations "in [his] head" and then the markings required to define the amount and type of wood that he needs to buy to build a roof, be it "round, square, any way". Like all who write, Mr. Sebastião draws, in his mind, a text with meaning for himself. By externalizing his thoughts through writing, he adopts a coding system that is different from the standard writing system taught by the schools, but it allows him to produce a text that tends to the formation of connections, the establishment of relations between different concrete impressions, to the union and generalization of distinct objects, the order and systematization of his experience as "roofer" - "5 X P X 146 7". That is, he produces a kind of writing that reflects his cultural experience as roofer and producer of text, and still does not match the record that would be adopted in a writing class - " 5 pieces of $7 \times 0.14 \times 0.06 \mathrm{~m}^{3}$ ".

In determining the quantity and measurements of the wood pieces for the hypothetical roof construction, $\mathrm{Mr}$. Sebastião relies on tradition (based on experience) to make the roof beams (rectangular) with pieces of wood called " 15 by 8 " (or " 14 by 6"), and five in number. The length of the piece turns out to be the definition most likely to change, even if parameterized by the maximum span that a beam can "beat" or the maximum length of the wood available on the market.

The student demonstrates that knowledge is not stored in drawers, but preserved in memory, using a coding system, which creates a system of ideas. So what makes the memory can be revived and developed by individuals (Luria, 2008) in social interactions.

\section{Concluding Remarks}

In the dialogue between Mr. Sebastião and the researcher, different subjects participate and reveal their cultural affiliations, their knowledge and the relationships they are building with reading and writing. The situation experienced by Mr. Sebastião, as being in and of the world, in making use of his graphic code, unlocks the problem to be solved: to record his purchase order for 
work materials, "if I haven't write it down I was in trouble". Challenged by the situation of interaction with the researcher, he reflects on the appropriation of a writing system, in a cogniscent act that provokes new understanding of the challenge. And this cognitive exercise makes it possible to critically reflect on his reality and its effect on hers. According to Freire (1970/2005), "this reflection on the situationality is a thought on the very condition of existence. A critical thought through which men find themselves in a situation” (p. 118).

When discovered, the subjects transform themselves and the learning process of reading and writing into a process of discovering new words and new meanings. These senses are initially constructed in the personal experience (principally in the family and work environments). The school experience allows them to extend those senses, or make them stronger or more flexible, as it brings new meaning to personal experiences. The mediation of language is crucial in this process. According to Luria (2008), "language is a fundamental part of every process of perception, memory, thinking, behavior and cognition through which we analyze our perceptions, we distinguish what is essential and what is not, and establish categories of different impressions” (p. 50), as well as organizing our inner life. Mr. Sebastião tell us part of is history as reflection of philosophical nature: "You see/the kind of mind of the people!" The "kind of mind of the people" is variable and, therefore, surprising, because it is constituted by the diversity of sociocultural practices that we live.

This inserts in our discussion the cultural nature of appropriation of knowledge, as situated, distributed, interpretative and constructive, which "proceed as much from the outside in as the inside out, as much from culture of mind to mind of culture" (Bruner, 1990/1997, p. 95). Thus, we inquire about the use of symbolic systems of culture, their language and modes of discourse, forms of logical explanation and narrative, and patterns of mutual dependence of ordinary life (Bruner, 1990/1997) of our students, especially students of AE. We are concerned that the school allows them the appropriation of scientific/school concepts, but also promotes their participation in the process of self-construction that mobilizes capacities for reflection and projection of alternatives for themselves.

In the process, these $\mathrm{AE}$ subjects can conceive other modes of being, acting and engage in cultural practices (Bruner, 1990/1997), given that their own practices constitute themselves as "content" of teaching-learning, requiring the exercise of metacognition that promotes improvements in their mental and cultural development. Development associated with literacy and education promoted the withdrawl from the experience in the concrete reality and immersion of students, like Mr. Sebastião, in scientific/school and cultural activities, leading them to a "greater self control, self-regulation and transcendence from the world of immediate experience" (Oliveira, 1999, p. 57).

We agree with Freire (1982/1996) that men are unfinished beings capable of having for themselves and their own activity as objects of consciousness and reflection. They are therefore aware of themselves and of the world and, to the extent that they objectively distance themselves from their activity, they are also capable of overcoming "limiting situations" through concrete action over reality. Through their action in the world, men create the field of culture and history, and only they are beings of praxis, reflection, creation of material goods, their social institutions, their ideas and their conceptions: "You see/the kind of mind of the people!" The type of mind which is an extension of the hands and the tools used by Mr. Sebastião, and the researcher who conversed with him, because the practices of the work of both established an intimate relationship between culture and cognition mediated by language within and outside the school, making each of them very different historical and cultural subjects, with different "types of minds" and, therefore, with different opportunities for learning and development. In the formation of these differences, an intimate relationship is revealed between doing and knowing, and the contribution of education in the transition from concrete thought (everyday) to the abstract (scientific/school) and vice versa, between the mental plane and objective reality (Oliveira, 1999 ).

\section{References}

Agar, M. (2002). Language shock: Understanding the culture of conversation. New York: Perennial.

Bakhtin, M. (Voloshinov) (1992). Marxismo e Filosofia da Linguagem. São Paulo, SP: Hucitec.

Bruner, J. (1997). Atos de significação (S. Costa, Trad.). Porto Alegre, RS: Artes Médicas. (Original work published 1990)

Bruner, J. (2001). A cultura da Educação (M. A. G. Domingues, Trad.). Porto Alegre, RS: Artmed. (Original work published 1996)

Castanheira, M. L. (2004). Aprendizagem contextualizada: Discurso e inclusão na sala de aula. Belo Horizonte, MG: Editora da Universidade Federal de Minas Gerais.

Cole, M. (2006). Culture and cognitive development in phylogenetic, historical, and ontogenetic perspective. In W. Damon, R. M. Lerner (Series Eds.), D. Kuhn, \& R. S. Siegler (Vol. Eds.), Handbook of Child Psychology: Vol. 2. Cognition, perception and language ( $6^{\text {th }}$ ed., chap. 15$)$. New York: Wiley. Cole, M., \& Scribner, S. (1974). Culture and thought. New York: John Wiley and Sons.

Collins, E., \& Green, J. L. (1992). Learning in classroom settings: Making or breaking a culture. In H. Marschall (Ed.), Redefining students learning roots of educational changes (pp. 59-85). Norwood, NJ: Ablex.

Fairclough, N. (1993). Discourse and text: Linguistic and intertextual analysis within discourse analysis. Discourse and Society, 3(2), 193-218. 
Gomes, M. F. C., Fonseca, M. C. F. R., Dias, M. T. M. \& Vargas, P. G. (2011). Culture, Cognition and Language in the Constitution of Reading and Writing Practices in an Adult Literacy Classroom.

Fonseca, M. C. F. R. (2001). Lembranças da matemática escolar: A constituição dos alunos da EJA como sujeitos da aprendizagem. Educação e Pesquisa, 27(2), 339-354.

Fontana, R. A. C. (1996). Mediação pedagógica na sala de aula: Educação contemporânea. Campinas, SP: Autores Associados.

Fontana, R. A. C., \& Cruz, N. (1997). Psicologia e trabalho pedagógico. São Paulo, SP: Atual.

Freire, P. (1996). A importância do ato de ler em três artigos que se completam. São Paulo, SP: Autores Associados. (Original work published 1982)

Freire, P. (2005). Pedagogia do oprimido. Rio de Janeiro, RJ: Paz e Terra. (Original work published 1970)

Gee, J., \& Green, J. L. (1998). Discourse analysis, learning, and social practice: A methodological study. In P. D. Pearson (Ed.), Review of research in education (Vol. 23, pp. 119-169). Washington, DC: American Educational Research Association.

Góes, M. C. R. de. (2000). A abordagem microgenética na matriz histórico-cultural: Uma perspectiva para o estudo da constituição da subjetividade. Cadernos CEDES, 20(50), 9-25.

Gomes, M. F. C., Dias, M. T. M., \& Silva, L. P. (2008). O registro da rotina do dia e a construção de oportunidades de aprendizagem da escrita. In M. L. Castanheira, F. I. P. Maciel, \& R. F. Martins, Alfabetização e letramento na sala de aula (pp. 59-74). Belo Horizonte, MG: Autêntica.

Gomes, M. F. C., \& Mortimer, E. F. (2008). Histórias sociais e singulares de inclusão/exclusão na aula de química. Cadernos de Pesquisa, 133(8), 237-266.

Green, J. L., Dixon, C., \& Zaharlic, A. (2001). Ethnography as a logic of inquiry. In J. Flood, D. Lapp, J. Jensen, \& J. Squires (Eds.), Handbook for research on teaching the English language arts ( $2^{\text {nd }}$ ed., pp. 1-26). Mahwah, NJ: Lawrence Erlbaum.

Green, J. L., \& Harker, J. O. (1982). Gaining access to learning: Conversational social and cognitive demands of group participation. In L. C. Wilkinson (Ed.), Communicating in the classroom (pp. 46-76). New York: Academic Press.

Green, J. L., \& Wallat, C. (1981). What is an instructional context? An exploratory analysis of conversational shifts across time. In O. Garnica \& M. King (Eds.), Language, children, and society (pp. 159-188). London: Pergamon Press.

Gumperz, J. (1986). Interactive sociolinguistics on the study of schooling. In J. Cook-Gumperz (Ed.), The social construction of literacy (pp. 45-68). New York: Cambridge University Press.

Luria, A. R. (2008). O homem com um mundo estilhaçado: Textos fundantes de Educação. Petrópolis, RJ: Vozes.

Middleton, D., \& Edwards, D. (1990a). Memoria compartida: la naturaleza social del recuerdo y del olvido. Barcelona, España: Paydós.

Middleton, D., \& Edwards, D. (1990b). Recuerdo conversacional: un enfoque socio-psicológico. In D. Middleton \& D. Edwards (Eds.), Memoria compartida: la naturaleza social del recuerdo y del olvido (pp. 39-62). Barcelona, España: Paydós.

Oliveira, M. K. (1999). Jovens e adultos como sujeitos de conhecimento e aprendizagem. Revista Brasileira de Educação, 12, 59-73.

Oliveira, M. K. (2009). Cultura \& Psicologia: Questões sobre o desenvolvimento do adulto. São Paulo, SP: Aderaldo \& Rotschild.
Oliveira, M. K., \& Oliveira, M. B. (Eds.). (1999). Investigações cognitivas: Conceitos, linguagem e cultura. Porto Alegre, RS: Artes Médicas Sul.

Orlandi, E. P. (1987). A linguagem e seu funcionamento: As formas do discurso. São Paulo, SP: Pontes.

Santa Barbara Classroom Discourse Group. (1992). Constructing literacy in classrooms: Literate action as social accomplishment. In H. H. Marschall (Ed.), Redefining student learning: Roots of educational change (pp. 119-150). Norwood, NJ: Ablex.

Scribner, S., \& Cole, M. (1981). The Psychology of Literacy. Cambridge, MA: Harvard University Press.

Smolka, A. L. B. (1999). A criança na fase inicial da escrita: A alfabetização como processo discursivo. São Paulo, SP: Cortez.

Spradley, J. P. (1980). Participant observation. New York: Holt, Rinehart and Winston.

Vygotsky, L. S. (1979). Pensamento e linguagem. Lisboa, Portugal: Antídoto. (Original work published 1934)

Vygotsky, L. S. (1989). A formação social da mente: O desenvolvimento dos processos psicológicos superiores. São Paulo, SP: Martins Fontes.

Vygotsky, L. S. (1993). Obras Escogidas: Vol. 2. Madrid, España: Visor. (Original work published 1934)

Wertsch, J. V. (1988). Vygotsky y la formación social de la mente. Barcelona, España: Paidós.
Recebido: 17/11/2009

$1^{a}$ revisão: 22/06/2010

$2^{a}$ revisão: 09/09/2010

Aceite final: 10/09/2010 